\title{
The Securityness of Secularism? The Case of Turkey
}

\author{
PINAR BILGIN* \\ Bilkent University, Ankara, Turkey
}

Secularism is frequently portrayed as a security referent in presentday Turkey. But, what is it that makes secularism a security issue? Where are we to locate the 'securityness' of secularism? Against prevailing accounts that privilege the domestic dimension, this article argues that the securityness of secularism in Turkey should be located in both the domestic and the international. This is not to suggest that secularism can be reduced to security, but it is to suggest that efforts to portray Turkey's secularism merely as a constitutive principle and an outcome of the project of Republican transformation, or as a means of safeguarding a particular vision of transformation through controlling religion, or as an instrument of national economic development, while rewarding in themselves, nevertheless miss an important set of dynamics that help to explain secularism's centrality to Turkey's politics. The article locates this latter set of dynamics in the international realm and ultimately proffers the argument that secularism was in part a response to European/international society's ambivalence towards Turkey's 'difference' and the insecurities this entailed. The conclusion suggests that the present-day centrality of secularism in Turkey's politics and the apparent securityness of such centrality could be considered as a response to particular remembrances of the past and interpretations of the present vis-à-vis such ambivalence.

Keywords security • secularism • Turkey • critical security • international society

I

N PRESENT-DAY TURKEY, secularism is frequently portrayed as a security referent - something that is under threat and that needs safeguarding. ${ }^{1}$ Those who belong to the highest echelons of the state underwrite the

1 Throughout this article, I use the term 'secularism' as opposed to the more appropriate 'laicism', while recognizing that Turkey's interpretation and practices do not exactly fit either Anglo-Saxon models of secularism or the French laïcité. Even though Turkey's version of secularism was modelled after France (as evinced in the use of the word laiklik), the experiences of the past 80 years have deviated from the French ideal type (Asad, 2003; Hurd, 2004; Taylor, 1998). Although I agree with Davison (2003: 334) on the point that Turkey's self-understanding and practices are better captured with the concept of laicism than with the concept of secularism', I have nevertheless chosen to use 'secularism' in reference to Turkey's laiklik to avoid further complicating the narrative. 
status of secularism as a key referent when they write irtica (obscurantist reactionarism) into the national security agenda. ${ }^{2}$ But, what is it that makes secularism a security issue? Where are we to locate the 'securityness' (Wæver, 1995b) of secularism?

Inquiring into the securityness of secularism is not meant to question whether obscurantist reactionarism constitutes a threat to security in Turkey or elsewhere. Rather, it rests upon the theoretical premise that 'danger is not an objective condition' (Campbell, 1992: 1) but is socially constructed. Understanding how the Soviet placement of missiles in Cuba in 1962 (Weldes, 1999; Weldes \& Saco, 1996) and the Iraqi invasion of Kuwait in 1990 (Campbell, 1993) became dangers to US security, for instance, requires examining what David Campbell (1992) has termed 'discourses of danger' the set of validity claims through which someone or something is represented as under threat and in need of safeguarding. Studying insecurity as a social construct involves examining such representations through which individuals describe to themselves and to others the world in which they live' (Weldes et al., 1999: 14) and which constitute their insecurities, identities and interests (McSweeney, 1999). Needless to say, taking threats as socially constructed does not render them less 'real' - unless, that is, one claims unmediated access to 'reality'.

As such, understanding secularism's present-day status as a key security referent in Turkey involves paying close attention to the 'discourses of danger' through which its securityness has been constructed. For, 'the meaning of a concept is in its usage' (Wæver, 1995b: 226). This is not to deny that the set of validity claims through which insecurities are produced is 'subject to redemption through argumentation' (Wyn Jones, 1999: 111); nor is it to underplay Ken Booth's (2008: 165) misgivings about 'discourse-centric' approaches to the study of security. Rather, the aim here is to underscore the insights to be gleaned from inquiring into the securityness of a particular issue.

As will be seen below, my analysis of Turkey's case uncovers an intimate historical relationship between secularism and security. ${ }^{3}$ This relationship should not be viewed as restricted to helping safeguard secularism once it was initiated (as the literature suggests), for its origins can be found in the 'non-specific and non-military' security concerns of the founding leaders during the early years of the Republic - some of which remain in different guises in present-day Turkey. ${ }^{4}$ The non-specific and non-military security problem encountered by Turkey's founding leaders was one of seeking a

\footnotetext{
2 The other top agenda item is Kurdish separatism.

${ }^{3}$ This is not to suggest that security was the only or the most important motive behind Turkey's turn to secularism. The gains of secularism for Turkey's society and institutions are numerous and need not be listed here. Nor is it to reduce Turkey's early Republican security policies to Westernization and/or secularization.

${ }^{4}$ For a preliminary analysis of Turkey's security imaginary, see Bilgin (forthcoming).
} 
way to negotiate difference given European/international society's ambivalence toward their 'difference'. Religion at the time was considered the most significant marker of this difference. ${ }^{5}$ The founding leaders seem to have found a part of the solution in the turn to secularism. In pointing to such an intimate relationship between secularism and security, I draw on accounts by Ole Wæver (1995a, 1998) and Bill McSweeney of European integration as a 'security policy in response to a non-specific and non-military security problem' (McSweeney, 1999: 8), as well as Michael Williams's (1998) analysis of modernity's 'quest for certainty' as a response to the 'security concerns of the early modern era'. Thus, the securityness of secularism becomes an issue to be explored through locating the recourse by Turkey's actors to 'discourses of danger' in its social and historical context.

In what follows, I suggest that the securityness of secularism in Turkey should be located in both the domestic and the international. While I seek to contribute to the literature that discusses the centrality of secularism to Turkey's politics with reference to domestic concerns, I also seek to recast these discussions by pointing to the international dimension. This is not to suggest that secularism can be reduced to security, but it is to suggest that efforts to portray Turkey's secularism merely as a constitutive principle and an outcome of the project of Republican transformation (the 'separation' account), or as a means of safeguarding a particular vision of transformation through controlling religion (the 'control' account), or as an instrument of national economic development (the 'material advancement' account), while rewarding in themselves, nevertheless miss an important set of dynamics that help to explain secularism's centrality to Turkey's politics both at the moment of its initiation and in the present day. I locate this latter set of dynamics in the realm of the international and ultimately proffer the argument that secularism was in part a response to international society's ambivalence towards Turkey's 'difference' and the insecurities this entailed. ${ }^{6}$

The argument is built as follows: The first section looks at the aforementioned three accounts that prevail in the literature on Turkey's politics. These three accounts (and their variants) capture different (domestic) security aspects of the centrality of secularism to Turkey. Their differences lie in what they regard as the referent object and the nature of threats. My aim in this section is one of drawing out what often remains unarticulated in the scholarly

${ }^{5}$ Here is an example of how their European counterparts portrayed the Ottomans in 1878: 'They are Mahometans on Christian ground... . They are exceptional Mahometans in a Christian system. The difficulties created by their position are great; but for four hundred years they have not been great enough to prevent the Christians doing practical business with them. . . . As Mahometans they are ... impracticable members of the European system' (cited in Deringil, 1998: 136).

6 The persistence of such concerns regarding ambivalence toward Turkey's difference could be discerned from the ways in which the European Union's call for rethinking Turkey's particular conception and practices of secularism is portrayed by those at the highest echelons of the state as a threat to Turkey's security (see Ergan, 2006; Ergin, 2004). 
writings and articulating this in security terms. At one level, there is no need for translation as such, for these writings are suffused with 'discourses of danger'. At another level, however, there is a need for translation, because the literature discusses threats without explicitly identifying who or what the referent objects are. Accordingly, the differences between the three accounts regarding who or what is being safeguarded and against whom or what remain unarticulated.

The second section offers an account of the international dimension of the securityness of secularism through contextualizing the turn to secularism by Turkey's founding leaders. Following a brief exposé of the founding leaders' recourse to 'discourses of danger' in making the case for Turkey's turn to secularism, I lay out how Turkey's secularism could also be read as a response to non-military and non-specific security concerns rooted in the ambivalence of European/international society toward Turkey's difference. Locating the securityness of security (partly but not wholly) in the international realm would thus help us better understand both the centrality of secularism to Turkey's politics and myriad expressions of such centrality through 'discourses of danger'. A concluding section summarizes the argument and suggests that the present-day centrality of secularism and the securityness of such centrality could be considered a response to particular remembrances of the past and interpretations of the present vis-à-vis such ambivalence.

\section{The 'Domestic' Dimension}

The literature on Turkey does not explicitly examine the securityness of secularism. ${ }^{7}$ Whereas secularism's centrality to Turkey's domestic politics is discussed elaborately (Berkes, 1957, 1964; Cizre-Sakallığlu, 1996; Daver, 1955; Göle, 1997; Mardin, 1977, 1981; Ozankaya, 1981; Toprak, 1981, 1988), the question why such centrality is expressed via 'discourses of danger'? is almost never asked. ${ }^{8}$ Where scholars disagree - not in so many words - is regarding who or what is being safeguarded through secularism and against what or whom. This section of the article will look at the aforementioned three main accounts $^{9}$ that prevail in the literature and tease out the ways in which they capture different (domestic) security aspects of the centrality of secularism to Turkey's politics.

7 Those rare studies that scrutinize the securityness of secularism do this within the framework of civil-military relations and focus on the agency the military exercises through the National Security Council in shaping the security agenda (see Tank, 2005).

8 This is not meant as a critique. Critical approaches to security have begun to gain ground in Turkey and elsewhere only since the mid-1990s.

9 The first two accounts are adopted in modified form from Davison (1998). The third is my characterization of the Davison and Parla argument (Davison, 1998; Parla \& Davison, 2004). 


\section{The 'Separation' Account}

The 'separation' account considers secularism as both a constitutive principle and an outcome of the project of Republican transformation (see, among others, Daver, 1955; Kili, 1980, 2003; Lewis, 1961; Ozankaya, 1981; Tachau, 1984; Tanör, 1998; Yavuz, 1990). According to the proponents of this account, secularism was adopted as part of a project of emancipation by the Republic's founding leaders, who sought to separate the affairs of religion from those of the state, thereby pushing out the political and legal manifestations of Islam. The political and societal gains that ensued, according to this account, explain the centrality of secularism to Turkey's politics. Consider the following quote from Suna Kili (2003: 244-245):

In Atatürk's Turkey, in accordance with the requirements of modernization, religion and religious institutions were removed from areas, such as education and law, which did not fall within the proper sphere of their activity. And in their place, laic concepts and institutions were substituted. Historical experience with the religious groups' opposition to modernization had a profound impact on the formulation of the Atatürkist principle of laicism.

In Kili's formulation, religion and religious institutions are portrayed as blocking the path to modernization; they are criticized for having hindered the progress of the Ottoman Empire and for disallowing attempts at reviving such progress, thereby rendering the Empire insecure. Other authors concur: the Ottoman experience had proven the futility of attempts to transform without secularization (Ozankaya, 1981; Tachau, 1984; Yavuz, 1990).

Put in security terms, proponents of the 'separation' account consider the threat to be a possible revival of the Ottoman past; what is being protected is the Republic of Turkey as a project of transformation. The securityness of secularism, in this account, rests on: (1) secularism's having allowed the Republican transformation and the project of emancipation through separating religiously justified arguments and scientifically justified arguments, and pushing the former outside the realm of politics and education; (2) its having helped to secure the Republican transformation against the future assails of those who might seek to reimpose the Shari'ah upon society and politics, thereby putting the gains of emancipation at risk. As such, the 'separation' account explains both the initiation and the present-day centrality of secularism in Turkey with reference to domestic security concerns.

\section{The 'Control' Account}

Although authors disagree as regards the reasons for and agents of 'control', their arguments converge in explaining the centrality of secularism with reference to the role it has played in disciplining the opposition, thereby keeping in track a particular vision of transformation (Cizre-Sakallığlu, 
1996; Gülalp, 2005; Keyder, 1987, 2004; Mardin, 1977, 1981; Rustow, 1957; Toprak, 1981, 1988). According to Binnaz Toprak (1981), secularism in Turkey served not to separate religion and politics (as in the 'Western' model of church-state separation) but to control religion for the purposes of the government in office while casting the opposition's resort to religiously justified arguments and/or actions in an unfavourable light. This was because, Toprak (1988: 120) wrote,

religion in Turkey, especially during the formative years of the Republic, had been the most important centrifugal force with a potential to challenge the state. It is partly for this reason that the separation of religion and state was never attempted in its Western version as Orthodox Islam was put under state control and made subservient to state authority.

Since the opposition tapped this 'centrifugal force' and employed religiously justified arguments, suggests Toprak, the state resorted to using secularism to control religion, the ultimate aim being safeguarding the founding leaders' vision for transformation in Turkey. In variations of this account, Şerif Mardin $(1977,1982)$ traces the state practice of 'controlling' religion back to Ottoman practices; Çağlar Keyder (1987) synthesizes the insights of Toprak's 'control' and Mardin's (1973) 'centre-periphery' arguments and maintains that, following the initiation of secularism in the early Republican period, Turkey's particular conception and practices of secularism have allowed the 'centre' to keep the 'periphery' at bay throughout the Republican era.

Expressed in security terms, the 'control' account paints a picture in which those alternative visions of transformation that tapped religion are the threat; what is being safeguarded is the particular vision of transforming Turkey conceived by Atatürk and his closest associates. The securityness of secularism, accordingly, rests on the latter's having allowed: (1) marginalizing those who favoured alternative visions; (2) underpinning the founding leaders' vision of transformation by controlling religion as they saw fit. Thus, the 'control' account, too, explains the initiation and present-day centrality of secularism in Turkey with reference to domestic security concerns.

\section{The 'Material Advancement' Account}

The third and lesser-known account is offered by Andrew Davison and Taha Parla, who reject the 'separation' and 'control' accounts and offer, in their stead, an account that details and historicizes the self-understandings and justifications of the founders of the Republic as seeking 'certain separations in a context of overall control' (Davison, 1998: 163; see also Parla \& Davison, 2004). Against those who propound the 'control' account, Davison and Parla insist that the founding leaders' exercise of control involved seeking a degree of separation. However, they also point out - in contrast to the proponents of the 'separation' account - that this was not the same as the practice of sepa- 
ration of church and state found in some Western contexts..$^{10}$ The Republican leaders' secularism, they argue, was a unique mix of 'separation' and 'control' designed to make something else possible: material advancement. There resides the centrality of secularism in Turkey's politics according to Davison and Parla: in the realm of national economic development. It is worth quoting Davison (1998: 172-173) at length:

In accordance with the RPP's [Republican People's Party] reading of the requirements of contemporary civilization; and to secure the RPP's hegemony and definition of national aims in legal, social, educational, cultural and economic matters; and to gain respect for national sovereignty in the internal and external political circumstances in which the national movement existed; religion was removed from its previous position of power, separated in this sense, overdefining the theory and practice of legal, social, cultural, and economic spheres wherein it was seen as a fetter, causing arbitrary, confused, primitive, and medieval governance, lethargy, and harmful ills to the people of the Turkish nation.

A careful hermeneutic analysis of the founding leaders' discourses led Davison and Parla to conclude that the Republican leaders considered it essential to turn to secularism if Turkey were to succeed as a state. The centrality of secularism for Turkey, according to this account, rests in secularism's having allowed Turkey's development at a particular historical period where rapid 'material advancement' was crucial for its survival.

Put in security terms, Davison and Parla identify the threat as the prospect of failing to 'achieve success in the material world' (Davison, 1998: 165; see also Parla \& Davison, 2004: 118-125); what is being safeguarded is the future of the Republic as an economically successful independent sovereign state. It is significant to note here that, unlike the previous two accounts, the 'material advancement' account seeks to explain the centrality of secularism at the moment of its initiation; Davison and Parla do not elaborate on the presentday centrality of secularism in Turkey - or the securityness of such centrality.

To recapitulate, what is common to these three accounts - irrespective of their differences regarding who or what secularism has helped to safeguard, and against what or whom - is their portrayal of the centrality of secularism vis-à-vis actual or imminent domestic threats, the implication being that the centrality of secularism to Turkey's politics and the apparent securityness of such centrality is a function of domestic concerns alone.

\section{The 'International' Dimension}

This section begins by examining the extent to which the literature on Turkey considers international dynamics in accounting for the centrality of secularism in Turkey. I will go through the three accounts discussed above to see

${ }^{10}$ See Chatterjee (1998) for a similar argument with reference to the Indian context. 
whether/how they incorporate the international, and suggest that they fall short of accounting fully for the intimate historical relationship between secularism and security, which has had both domestic and international dimensions. Next, I will account for the latter by showing how Turkey's turn to secularism in part was a response to non-military and non-specific security concerns rooted in European/international society's ambivalence towards Turkey's difference.

\section{The 'International' in the Literature on Turkey}

When they factor in international dynamics - if they do so at all - proponents of the three accounts discussed above confine the significance of such dynamics to secularism's initiation. While the 'separation' account refers to the international in explaining the rationale for the abolishment of the caliphate, the 'control' account mentions it only in passing. The 'material advancement' account goes further than the other two and points to the founding leaders' search for international justification for their project of transformation.

According to the proponents of the 'separation' account, not only domestic but also international dynamics featured in the decision to abolish the caliphate, a crucial step in the project of Republican transformation. ${ }^{11}$ Ottoman sultans had acquired the right to use the title of caliph when they defeated the Mamluk Sultanate in 1517, but did so infrequently, with the exception of Sultan Abdulhamid II. The caliphate was abolished by the Republican leaders on 3 March 1924 by an act of parliament. In explaining this act, scholars who favour the 'separation' account maintain that the caliphate had to be abolished because it had become a burden for Turkey's international relations, particularly with those colonial powers that ruled over Muslim peoples. Kili makes use of Halide Edip Adıvar's 1930 rendering of the early days of the Republic to explain such concerns on the part of the founding leaders. According to Adivar, who was one of the leading figures of the nationalist struggle ${ }^{12}$ the caliphate was complicating relations with colonial powers of Europe. In her words, these 'either suspected Turkey constantly of scheming against their sovereignty, or else they themselves were involved in intrigue in Turkey in order to get control of the caliphate and use it on behalf of their own ambitions' (Adıvar cited in Kili, 2003: 356). Kili maintains that the abolishment of the caliphate removed not only the grounds for such interference into Turkey's affairs but also a cloud of suspicion regarding the ambitions of the founding leaders by making it clear that these were confined to the boundaries of Turkey.

11 On the centrality of the abolishment of the caliphate in the struggle between Atatürk and his opponents, see İnalcık (2006: 93-104).

12 On Adivar, see Adak (2003). 
The proponents of the 'separation' account thus point to one important aspect of the international dimension to Turkey's turn to secularism - that the Ottoman legacy (in particular, the legacy of Sultan Abdulhamid II's use of Islam for purposes of legitimacy and empowerment in the international realm) ${ }^{13}$ carried the potential to complicate the international relations of the young Republic. Adivar's references to international 'intrigues' and the Republic's concerns regarding its hard-won 'sovereignty' intimate at the securityness of this crucial step taken towards secularism as seen through the eyes of the founding leaders. ${ }^{14}$ That said, the 'separation' account's interest in the international remains limited to the 1920s and falls short of explaining the securityness of secularism in present-day Turkey.

The 'control' account leaves even less room for the international. The centrality of secularism to Turkey's politics and the securityness of such centrality are explained with reference to domestic insecurities faced by the founding leaders and their successors in later years. The 'material advancement' account, in turn, is singular in terms of the emphasis it puts on the international in explaining how the turn to secularism was instrumental in the founding leaders' search for international justification for the project of Republican transformation. Indeed, Davison and Parla consider Turkey's turn to secularism in the early Republican era not only as a part of the broader project of national economic development, but also as an integral aspect of the overall strategy that made room for such advancement, that is, through helping pursue a 'political and rhetorical legitimation strategy' internationally (Parla \& Davison, 2004: 116-125). That said, neither Davison nor Parla elaborates on these concerns beyond historicizing and contextualizing Turkey's particular conception and practices of secularism ('certain separations in a context of overall control'; see Parla \& Davison, 2004: 102-104). Nor do the authors consider whether these concerns were limited to the initiation of secularism in the early Republican era or whether they could also help explain its centrality in Turkey's politics in subsequent years and the securityness of such centrality. The explanatory power of the international, in the 'material advancement' account, is remarkable yet limited.

\section{Accounting for the International Security Concerns of the Founding Leaders}

In what follows, I will seek to substantiate my point regarding the intimate historical relationship between secularism and security by laying out how Turkey's turn to secularism could be considered (partly but not wholly) a response to non-military and non-specific security concerns rooted in European/international society's ambivalence towards Turkey's 'difference'. Following a brief exposé of the founding leaders' recourse to 'discourses of

13 On this, see Deringil (1998: 16-43).

14 One of Atatürk's closest associates, Falih Rıfkı Atay (1980), provides further evidence of such concerns. 
danger' in justifying the turn to secularism, the argument proceeds through clarifying the key notions upon which it is built, namely, 'non-military and non-specific security concerns', 'secularism as a security response', and 'international society's ambivalence towards Turkey's difference'.

\section{Turkey's Turn to Secularism in the Discourses of the Founding Leaders}

Secularism became a principle of the Turkish constitution in 1937. Notwithstanding my characterization of this move as a 'turn', secularism in Turkey may be better understood as a 'process' that began with the abolishment of the caliphate in 1924 and continued with powerful steps that included the abolishment of the Shari'ah and the medrese system (traditional schools where religion was the basis of instruction) in 1924; Islam being written out of the constitution in 1928; the adoption of a 'Western-style' dress code in 1925; the introduction of a new civil code (from Switzerland) and the Gregorian calendar in 1926; and the adoption of the Latin alphabet and script in 1928, the metric system in 1931, last names and the observance of Sunday as a holiday in 1934, and a new labour law (from Italy) in 1936. In what follows, I will look at three of these steps and the justifications the founding leaders used to make a case for taking them. These are the adoption of 'Western-style' dress (specifically 'the hat' as headgear), the new civil code, and the abolishment of the Shari'ah and the medrese system. The ultimate aim of this subsection is to illustrate the (international) securityness of secularism at the moment of its initiation as found in the discourses of the founding leaders.

The so-called hat law was issued on 25 November 1925, banning the use of the fez, the traditional male headgear. This change was put into practice as part of the effort to adopt Western-style dress. The move was designed partly to help unify the society by removing religious symbols as markers of difference (Kili, 2003: 172). Still, the decision was justified through recourse to 'discourses of danger' - not only in terms of the threat of societal fragmentation (as the rationale above suggests) but also in terms of survival in the international realm. At the time, the founding leaders portrayed the fez as a symbol that marked the Turks' difference from 'contemporary civilization'. They maintained that the adoption of the hat as headgear would help the world know that the Turk was no longer different but similar to them..$^{15}$ The urge to be similar, in turn, was portrayed as a matter of 'survival'. Consider the following quotes from an article published in the government-friendly Cumhuriyet in 1925. The author of the article maintained that the 'hat law' gave the following messages to the rest of the world: that the Turk was no longer different but similar to 'them'; that the Turk also 'has the right to live and be happy'; and that 'the Turk is a whole new world, with no difference

\footnotetext{
${ }^{15}$ Atatürk's closest associate, İsmet İnönü's granddaughter Gülsüm Bilgehan (1994), reports a similar exchange between her grandparents.
} 
from yours. ... The Turk is a person like you, wishing to make use of the fruits of civilization'. The author maintained that adopting the hat as headgear was helpful in getting these messages across because 'it was easier to show what was outside one's head compared to what was inside' (cited in Mert, 1998: 211; see also Berkes, 1964: 473-474). What is significant about the above-quoted lines is not that the symbolism of dress style is made use of, but that the use of such symbolism is justified through invoking security concerns. The adoption of the hat was framed in terms of the survival of the state, and not as a mere lifestyle choice.

The second example I will look at to illustrate the securityness of secularism at its initiation comprises the justifications used in a statement by the then justice minister Mahmut Esat (Bozkurt) on the occasion of the adoption of the (Swiss) civil code. It is worth quoting him at length:

Particularly in those states that are made up of citizens belonging to different religions, it is a must for national sovereignty purposes that the state delinks law and religion that is, if it is to enforce a single body of law. Because if laws were to be based on religion, a state that recognizes the freedom of conscience would then have to make separate laws for its citizens of different religious creeds. This, in turn, would go against the principle of political, societal and national unity that is warranted by contemporary statehood. It is important to underscore that the state is in interaction with not only its own citizens but also foreigners. In that case there arises the necessity to agree to the imposition of capitulations to regulate their behaviour. This was the most significant aspect of the rationale put forward by our counterparts during the Lausanne Treaty negotiations to make a case for the continuation of the capitulations (Bozkurt, 1926).

Bozkurt's words underscored major security concerns: preventing external interference into the affairs of the state on behalf of non-Muslim citizens, thereby garnering full sovereignty. Given the ways in which the 'right to interfere' was justified by the members of European/international society on the basis of the Ottoman Empire's 'backwardness' (by virtue of the role religion played in Ottoman governance) and utilized as part of intra-European rivalries during the later years of the Empire, the founding leaders of the Republic were concerned. One of their concerns was the legal status of nonMuslim citizens (and the proselytizing activities of various actors), which had proven to be a major source of insecurity during the later years of the Empire (see Deringil, 1998: 112-134). However, equally as sensitive as the legal status of non-Muslims was the need to ensure that European/international society recognized that special legal status was no longer needed to secure the rights and freedoms of non-Muslims. The secular character of the Republic of Turkey would guarantee the rights and freedoms of nonMuslims along with the rights and freedoms of the overwhelmingly Muslim majority of the populace.

The centrality of secularism to the Republic and the securityness of such centrality are expressed nowhere more clearly than in the following two 
quotes. The first is from an article by Vasfi Raşit [Sevig], a law professor and public intellectual with close ties to the founding leaders. The article was published on 27 August 1927 in Cumhuriyet. It was entitled 'laiklik' (secularism), long before secularism had become a constitutional principle but after the Shari'ah and the medrese system had been abolished. In it, Vasfi Raşit wrote:

consider how inadequate are the Anadolu and Rumeli citadels in ensuring the country's defence in this day and age ... similarly inadequate are the existing societal institutions in saving the country from its current catastrophe (cited in Mert, 1998: 209).

That the author likened the function of secularism in the new Republic to that of the citadels in the Ottoman Empire - that is, defence - is telling as regards the securityness of secularism and related reforms in the eyes of the founding leaders of the Republic.

The second quote from is Ahmet Ağaoğlu, a journalist and close adviser to Atatürk during the 1920s:

There are now two roads for us to follow: to accept defeat and annihilation or to accept the same principles which have created contemporary Western civilization. If we want to survive, we have to secularize our view of religion, morality, social relations, and law. This is possible only by accepting openly and unconditionally the mind as well as the behaviour of the civilization which we are bound to imitate (cited in Berkes, 1964: 465).

Both authors portrayed the turn to secularism as no ordinary move. It was a security response.

Having illustrated the 'discourses of danger' found in the discourses of Turkey's founding leaders, the present article will now turn to clarifying the key notions upon which its main argument is built (that is, that Turkey's secularism was partly a security response to non-specific and non-military security concerns in the face of European/international society's ambivalence towards Turkish difference). I will begin with the notion of 'non-specific and non-military security concerns' before discussing how secularism could be conceived as a response to them.

\section{Non-Military and Non-Specific Security Concerns}

One of the main characteristics that distinguish critical approaches to security from their mainstream counterparts is the emphasis they put on the nonmilitary dimensions of security. The focus on non-military security within critical approaches is not a consequence of the broadening of security agendas worldwide, but an effect of - what Booth $(1991,2008,2005)$ has termed 'deepening security' to reveal the relationships between myriad referents' philosophical stance, identities, interests and insecurities. Thus, non-military security concerns are integral to actors' reconstitution of their identities and interests to safeguard against myriad insecurities. 
The critical security literature points to European integration as a key historical instance of actors responding to a non-military and non-specific threat through reconstituting their identities and interests. To quote McSweeney (1999: 7):

Whatever the personal motives of the individuals who founded it, the EU was a security policy from its inception. Even with the calculated exclusion of military defence, the process of integration itself bound the member-states in a network of interdependence which made the recourse to military means of resolving disputes progressively more difficult.

The threat European actors were responding to was non-specific and nonmilitary because, in contrast to NATO's targeting of possible Soviet expansionism, they had a less visible enemy. They sought to respond to those insecurities that were feared to follow a possible return to past conflicts structured around old conceptions of identity and interests (McSweeney, 1999; Wæver, 1995a, 1998).

Taking my cue from this rendering of European integration as a response to security concerns of a non-military and non-specific nature, I offer a reading of Turkey's founding leaders' turn to secularism as a response to nonmilitary and non-specific security concerns. The threat to the Republic was non-military in that the gains of Turkey's national struggle had been sealed through the Lausanne Treaty in 1923. Yet, while Lausanne had reaffirmed Turkey's hard-won sovereignty, independence and territorial integrity, the founding leaders were nevertheless concerned about the fragility of such recognition. Accordingly, the threat they sought to respond to was nonspecific in that they were not targeting a specific act of a specific counterpart. Rather, their policies were designed to respond to what the future might bring, based on the leaders' particular remembrances of the past and interpretations of the present.

\section{Secularism as a Response to Insecurities}

In reading secularism as a security response, I follow Michael Williams (1998), who reminds us that in the history of 'modern' Europe, what helped to mediate difference in both the domestic and the international realms was pushing religiously justified arguments outside the realm of politics. Williams's analysis, in turn, builds upon Stephen Toulmin's move to locate modernity's 'quest for certainty' in the insecurities of early 17th-century Europe. Against those who explain modernity as the 'outcome of substituting a rationally self-justifying method for the medieval reliance on tradition and superstition', Toulmin maintains that while the 'rationalists hoped to elevate questions of epistemology, natural philosophy, and metaphysics out of reach of contextual analysis', 'their attempt to decontextualize philosophy 
and natural science had its own social and historical context' characterized by insecurities rooted in clashes over/through religious conviction (Toulmin, 1990: 16, 44).

Williams's own analysis is on the presumed absence of identity in the study of international relations (IR). Taking issue with prevailing accounts, he points to how 'a specific conception of identity is in fact constitutive of, rather than missing from prevailing theories of International Relations and security' (Williams, 1998: 205). He reveals IR's apparent neglect of identity to be a 'historical legacy of a conscious attempt to exclude identity concerns from the political realm, or as what might be called a negative identity practice that is a central element in the liberal sensibility and its construction of the place of identity in understanding the politics of security' (Williams, 1998: 205).

What is significant in the accounts of Williams and Toulmin, so far as the purposes of this article are concerned, is that the intimate historical relationship between seeking to separate 'claims of faith' from 'claims of knowledge' and searching for security through secularism is not peculiar to the case of Turkey, but was witnessed in modernity's 'quest for certainty' and in academic IR's seeming neglect of identity. The former Toulmin (1990: 70) has uncovered as being a 'timely response to a specific historical challenge - the political, social, and theological chaos embodied in the Thirty Years' War'; the latter Williams (1998: 206) has revealed to be an attempt 'to construct a material and objective foundation for political practice'. Both cases were attempts at negotiating difference in the face of a non-military and nonspecific security concern.

It is in this sense that I seek to offer a reading of Turkey's turn to secularism as a security response. Domestically, leaving religiously justified arguments outside the realm of politics allowed the founding leaders not only to safeguard the interests of the 'core' elite, but also to construct 'a material and objective foundation for political practice' (to borrow Williams's formulation) and to make room for Turkey's national economic development through empowering positive education. Internationally, pushing a significant marker of their difference into the private realm allowed the founding leaders to give a security response not dissimilar to modernity's answer to identity-driven violence. As Williams (1998: 214) notes, 'just as conflicts within societies were to be avoided by this strategy [of reducing political identity to abstract individuality], so were those between them'. It is essential to quote him at length:

Similarly, in the international realm, other polities could in principle be threats - something more likely if they were not liberal - but they were not necessarily so. Whether they were or not in this view became an empirical question - an issue of material military capabilities. The stress on instrumental reason and material capabilities (strategy, as it has become to be narrowly defined in modern terms) represented a new political practice. No other sovereignty was in essence or by its very (ontological) nature 
a threat or challenge (consider the difference between this and the logic of religious conflict in the Thirty Years War). Whether they were or not was held to be an empirical question susceptible to the newly defined form of reasoned discourse in a public realm and capable, in principle, of practical coordination between states (Williams, 1998: 215).

Put differently, secularization of politics and knowledge had allowed pacification of international relations in the aftermath of bloody religious wars in Europe, both domestically and internationally.

Viewed in this way, Turkey's founding leaders' turn to secularism could be understood as an attempt to emulate the successes of secularism as a security response as experienced in Europe. Indeed, the proponents of the 'separation' and 'material advancement' accounts stress how the founding leaders sought to emulate such success. There is no denying that the gains of secularism in Europe were a source of inspiration for Turkey's founding leaders. That said, there was an added complexity in the case of Turkey. Secularism as a strategy of pacification helped to govern intra-European relations. European/international society, which was constructed during the period analysed by Toulmin and Williams, had had an ambivalent attitude toward the 'non-European'. It is to the founding leaders' apprehension vis-à-vis such ambivalence and the insecurities that it entailed that the present article will now turn.

\section{European/International Society's Ambivalence Toward (Turkey's) 'Difference'}

Beginning from the mid-17th century onwards, as intra-European relations were pacified, non-European peoples' difference was increasingly used to justify their treatment as less than equal and therefore less deserving of sovereignty and independence. The culture of imperialism, coupled with an Orientalist mind-set (Said, 1978), provided the grounds for claiming the 'right' to 'better' rule. Accordingly, throughout the colonial era, peoples around the world had to fight not only the military forces but also the culture of imperialism, for it was the culture of imperialism that had allowed various imperialist practices of military and non-military nature (Said, 1993).

Such unequal treatment of non-European peoples crystallized in the 'standards of civilization' discourse employed by European/international society. 'Standards of civilization' refers to 'the assumptions, tacit and explicit, used to distinguish those that belong to a particular society (by definition the "civilized")' (Gong, 1984: 172). In the evolution of European/international society, 'standards of civilization' had come to mean 'the test of admission for non-European nations' (Zhang, 1991: 7). The self-ascribed civilizing mission of the Europeans aside, 'standards of civilization' also proved instrumental for imperial powers in their interventions into the affairs of non-Europeans (Mazower, 2006; Suzuki, 2005). Whereas those who were altogether outside European/international society were considered not deserving of selfgovernance (as with India or Africa), others in the process of meeting the 
standards with a view to joining this society had to endure interventions of one form or another (such as China and Japan). Indeed, even as both of these latter countries were recognized as having passed the test of 'standards of civilization', they experienced the fickle and fragile nature of such recognition. While China had to insist that China should not be treated as an exception to 'the set of rules declared by the West to be universally binding in international relations' (Zhang, 1991: 15), Japanese experience with European/international society 'was not one of stability and order, but of insecurity' (Suzuki, 2005: 149).

The Ottoman Empire had experienced such treatment at first hand when the British took over Cyprus and sought to legitimize their continued occupation of the island through invoking the superiority of so-called Enlightenment and post-Enlightenment ideas that they introduced to replace what they portrayed as the 'useless' and 'impractical' education systems of the Greeks and the Ottoman Turks (Bryant, 2001). At the time, a similar propaganda campaign was also in effect throughout the Empire through the agency of Christian schools. After the 1860s, these were widely reported to have used education 'as a means of political indoctrination', thereby making 'identification with Western civilization seem the antithesis of everything Ottoman' (Karpat, 2000: 9). ${ }^{16}$

From the early 18th century onwards, the Ottoman leadership had identified such activities as 'threats' to its security and sought to address them through shifting its strategy from 'security through power' to 'security through order'. The latter meant seeking to become a member of European/ international society by meeting the 'standards of civilization'. Consider the following quote from an Ottoman statesman (1879):

The truth of the matter is that unless Turkey ... does from now on enter seriously and truthfully into the road of reform and accept the civilization of Europe in its entirety - in short, proves herself to be a reformed and civilized state - she will never free herself from the European intervention and tutelage and will lose her prestige, her rights, and even her independence (cited in Berkes, 1964: 185).

Notwithstanding the many gains of Ottoman attempts at transformation and the formal recognition extended to the Empire as a member of the Concert of Europe, Ottoman leaders had to endure the fickle and fragile nature of such recognition, as with the European refusal to remove the capitulations, which effectively branded the Empire as 'less than fully sovereign'.

Ottoman historian Selim Deringil (1998: 172) laid out the Ottoman conundrum in the following way:

the Ottoman saw himself as an equal participant in the zero-sum games of world politics, and demanded to be treated as such. The European saw him as an anomaly, a

16 This experience was not limited to the Ottoman Empire. As Agnew (2006: 185) noted, 'much nationalism and imperialism have found purpose and justification in religious differences and in proselytizing'. 
master who should really be servant, a ruler who should really be a subject. It was this dichotomy which produced the Ottoman obsession with image and a determination to defend it against all slights, insults and slurs.

Elsewhere, reactions to such portrayals of the 'non-European' as not deserving to rule (by virtue of not being 'civilized') and the interlinked 'European' claim to 'better' rule had taken various forms of resistance. In an unequal setting, where the hierarchical binaries of Western/Eastern or civilized/uncivilized were defined by the 'powerful', the 'weak' had invariably sought to resist by feigning 'similarity' - that is, being and/or becoming 'modern', 'civilized', 'Western' (Bhabha, 1994; Ling, 2002).

It was as a part of the struggle to be recognized as an equal, and therefore as deserving of the right to 'rule', that Ottoman statesmen engaged in exercises in image-building, which was essentially a 'symbolic statement of [the Empire's] right to exist in a world which was constantly trying to relegate it to history' (Deringil, 1998: 165). ${ }^{17}$ During Sultan Abdulhamid II's reign, for instance, 'attendance at the [world] fairs acquired a new importance', but the aim was to present the Empire 'as the leader of the Islamic world yet a modern member of the civilized community of nations' (Deringil, 1998: 154). The point being that, while feigning similarity, the Ottomans nevertheless retained the strongest of the symbols that rendered them 'backward' in the eyes of their European counterparts: the centrality of religion to the Empire's domestic politics and the Shari'ah as a system of governing its Muslim subjects. The founding leaders of the Republic of Turkey took one more step and turned to secularism.

\section{Conclusion: Negotiating Difference Through Secularism}

This article began with a question: where are we to locate the securityness of secularism in Turkey? After considering the existing answers in the literature (that is, in the domestic realm), I suggested that the current overemphasis on the domestic has produced an incomplete picture, for it overlooks the international. Looking at the international, in turn, allows better understanding of the intimate historical relationship between secularism and security in Turkey. Contextualizing - domestically and internationally - the founding leaders' turn to secularism revealed it to be (in part) an effect of the insecurities that followed international society's ambivalence towards Turkey's difference. Indeed, focusing purely on the domestic dimension has not only

17 Needless to say, providing a reading of Ottoman/Turkish transformation as 'mimicry' is not to reduce it to mere emulation. Nor does it foreclose capturing alternative modernities. Rather, it allows understanding transformation as part of a broader security response designed to remove the grounds for external interference so as to make room for sovereign development. 
rendered incomplete our understanding of the securityness of secularism at the moment of its initiation, but has also had consequences for our understanding of the intimate relationship between secularism and security in present-day Turkey. What is more, the existing accounts' under-emphasis of the international has allowed others to overemphasize the domestic dimension in explaining the present-day securityness of secularism (see Bilgin, 2008). While the proponents of these accounts cannot be held responsible for others' appropriation of their ideas, it is nevertheless significant to note that their under-emphasis of the international has had consequences for our understanding of elite recourse to 'discourses of danger' when safeguarding Turkey's particular conception and practices of secularism against internal and external challengers.

Consider, for instance, M. Hakan Yavuz (2003: 46), who, building upon the main tenets of the 'control' account, has asserted that throughout Turkey's history the state has considered 'large sections of its own society, rather than foreign countries, as its main threat'. ${ }^{18}$ Yavuz has here done away with the 'control' account's nuanced treatment of the early days of the Republic and the security concerns of the founding leaders, thereby reducing the securityness of secularism to the centre-periphery struggle, which, in fact, unravelled somewhat later. What is significant for my purposes here is that Yavuz's apparent abandon of the international, while seemingly helpful in explaining elite recourse to 'discourses of danger' against the challenges of the (reactionary) opposition, nevertheless leaves unexplained why the same elites have employed similar notions of threat in responding to Christian proselytizing in Turkey ${ }^{19}$ or the European Union's calls for the betterment of the religious rights and freedoms of minorities. ${ }^{20}$

That said, not all are convinced regarding the persistence of such security concerns (stemming from international society's ambivalent treatment vis-àvis Turkey's 'difference') in present-day Turkey or the room for such concerns in contemporary world politics. Ahmet Davutoğlu (2000), for instance, while recognizing the founding leaders' concerns with the fragility of Western recognition and the potential consequences of withholding such recognition, has nevertheless downplayed the basis for such concerns. Without wanting to underplay the author's point that the grounds for the

18 Yavuz's (2003) original phrase is the 'securitization of Islam'. However, his choice of words seems mistaken considering the gist of the argument he makes regarding the state establishment's targeting of 'Islam' as a threat to secularism. Accordingly, his is a critique of the securitization of secularism, not Islam.

19 The reforms passed in line with EU conditionality are represented as having allowed the rise of Christian proselytizing in Turkey; see Akşam (2005). Given the National Security Council's previous categorization of Christian proselytizing as a threat to national security, the use of such rhetoric has the potential effect of branding Turkey's accession to the EU as endangering its security (see Bilgin, 2005).

${ }^{20}$ The minorities in Turkey are non-Muslims, as defined in the Lausanne Treaty of 1923. In recent years, EU calls for the betterment of the religious rights and freedoms of both non-Muslims and the Alevi (see European Union, 2006) were portrayed at the highest levels as an attempt to create 'artificial minorities', thereby preparing the groundwork for dismembering Turkey; see Radikal (2007). 
hierarchical binaries of civilized/uncivilized and oriental/occidental should be subjected to critical scrutiny, it is of the essence to underscore the need to analyze such actions as the Republican leaders' turn to secularism by locating them within their proper historical and international political contexts. That secularization as a theory is currently questioned within academia (Berger, 2001) does not make the founding leaders' concerns regarding their difference less 'real'. Nor does it render the centrality of secularism in present-day Turkey and the securityness of such centrality less 'real'.

Indeed, the insecurities of particular societies are unique - as are their responses to such insecurities. Those who wish to challenge the prevailing conception and practices of secularism in Turkey would have to begin from the beginning: to historically contextualize the centrality of secularism to Turkey's politics and the securityness of such centrality. My attempt at presenting such an analysis revealed multiple insecurities that were addressed by the founding leaders' turn to secularism. Given the persistence of the European Union's ambivalence regarding Turkey's difference (Hurd, 2006), coupled with Turkey's actors' particular remembrances of the past and interpretations of the present vis-à-vis such ambivalence, understanding the historical securityness of secularism in Turkey is a must if we are to be able to better comprehend present dynamics and foresee the future.

* Pinar Bilgin is Associate Professor of International Relations at Bilkent University, Ankara. She is the author of Regional Security in the Middle East: A Critical Perspective (Routledge, 2005). Her recent work has appeared in European Journal of Political Research, Political Geography, Geopolitics, International Relations, Politics and Third World Quarterly. She can be reached at pbilgin@bilkent.edu.tr. She would like to thank Bilge Criss, Berivan Eliş and Security Dialogue's three anonymous referees for commenting on previous versions of this article. Research for the article was conducted during the author's 2006-07 residence as a fellow at the Woodrow Wilson International Center for Scholars, Washington, DC.

\section{References}

Adak, Hülya, 2003. 'National Myths and Self-Na(rra)tions', South Atlantic Quarterly 102(3): 509-527.

Agnew, John, 2006. 'Religion and Geopolitics', Geopolitics 11(2): 183-191.

Akşam (Istanbul), 2005. 'Din elden gidiyor' [Losing Our Religion], 3 January.

Asad, Talal, 2003. Formations of the Secular: Christianity, Islam, Modernity. Stanford, CA: Stanford University Press.

Atay, Falih Rıfkı, 1980. Çankaya. Ankara: Bateş.

Berger, Peter L., 2001. 'Reflections on the Sociology of Religion Today', Sociology of Religion 62(4): 443-454.

Berkes, Niyazi, 1957. 'Historical Background of Turkish Secularism', in Richard N. Frye, ed., Islam and the West: Proceedings of the Harvard Summer School Conference on the Middle East, July 25-27, 1955. The Hague: Mouton \& Co. (41-68). 
Berkes, Niyazi, 1964. The Development of Secularism in Turkey. Montreal: McGill University Press.

Bhabha, Homi K., 1994. The Location of Culture. London: Routledge.

Bilgehan, Gülsüm, 1994. Mevhibe. Ankara: Bilgi.

Bilgin, Pinar, 2005. 'Turkey's Changing Security Discourses: The Challenge of Globalisation', European Journal of Political Research 44: 1-27.

Bilgin, Pinar, 2008. 'The Politics of Security and Secularism in Turkey: From the Early Republican Era to EU Accession Negotiations', in Dietrich Jung \& Catharina Raudvere, eds, Religion, Politics and Turkey's EU Accession. London: Palgrave (139-156).

Bilgin, Pinar, forthcoming. 'Turkey's "Geopolitics Dogma": Searching for Epistemological Certainty at a Time of Ontological Insecurity', in Stefano Guzzini, ed., Fixing Foreign Policy Identity: 1989 and the Uneven Revival of Geopolitical Thought in Europe.

Booth, Ken, 1991. 'Security and Emancipation', Review of International Studies 17(4): 313-326.

Booth, Ken, ed., 2005. Critical Security Studies and World Politics. Boulder, CO: Lynne Rienner.

Booth, Ken, 2008. Theory of World Security. Cambridge: Cambridge University Press.

Bozkurt, Mahmut Esat, 1926. 'Medeni Kanun Esbabı Mucibe Lâyihası' [Rationale for the Civil Code]; available at http://www.belgenet.com/yasa/medenikanun/gerekce_ 1926.html (accessed 10 August 2008).

Bryant, Rebecca, 2001. 'An Aesthetics of Self: Moral Remaking and Cypriot Education', Comparative Studies in Society and History 43(3): 583-614.

Campbell, David, 1992. Writing Security: United States Foreign Policy and the Politics of Identity. Manchester: Manchester University Press.

Campbell, David, 1993. Politics Without Principle: Sovereignty, Ethics, and the Narratives of the Gulf War. Boulder, CO: Lynne Rienner.

Chatterjee, Partha, 1998. 'Secularism and Tolerance', in Rajeev Bhargava, ed., Secularism and Its Critics. Delhi: Oxford University Press (345-379).

Cizre-Sakallığlu, Ümit, 1996. 'Parameters and Strategies of Islam-State Interaction in Republican Turkey', International Journal of Middle East Studies 28(2): 231-251.

Daver, Bülent, 1955. Türkiye Cumhutiyeti'nde Layiklik [Laicism in the Republic of Turkey]. Ankara: A.Ü. S.B.F.

Davison, Andrew, 1998. Secularism and Revivalism in Turkey: A Hermeneutic Reconsideration. New Haven, CT: Yale University Press.

Davison, Andrew, 2003. 'Turkey, a "Secular" State? The Challenge of Description', South Atlantic Quarterly 102(2/3): 333-350.

Davutoğlu, Ahmet, 2000. 'Philosophical and Institutional Dimensions of Secularisation: A Comparative Analysis', in Azzam Tamimi \& John L. Esposito, eds, Islam and Secularism in the Middle East. New York: New York University Press (170-208).

Deringil, Selim, 1998. The Well-Protected Domains: Ideology and the Legitimation of Power in the Ottoman Empire, 1876-1909. London: I. B. Tauris.

Ergan, Uğur, 2006. 'Gizli Anayasa Tamam' [The Secret Constitution Is Ready'], Hürriyet (Istanbul), 20 March.

Ergin, Sedat, 2004. 'Milli Güvenlik Siyaset Belgesi değiştiriliyor' [The National Security Policy Document Is Being Revised]. Hürriyet (Istanbul), 24 November.

European Union, 2006. Turkey 2006 Progress Report; available at http://ec.europa.eu/ enlargement/pdf/key_documents/2006/Nov/tr_sec_1390_en.pdf (accessed 21 May 2007).

Göle, Nilüfer, 1997. 'Secularism and Islamism in Turkey: The Making of Elites and Counter-Elites', Middle East Journal 51(1): 46-58.

Gong, Garret W., 1984. 'China's Entry into International Society', in Hedley Bull \& Adam 
Watson, eds, The Expansion of International Society. Oxford: Clarendon Press (171-183).

Gülalp, Haldun, 2005. 'Enlightenment by Fiat: Secularization and Democracy in Turkey', Middle Eastern Studies 41(3): 351-372.

Hurd, Elizabeth Shakman, 2004. 'The International Politics of Secularism: U.S. Foreign Policy and the Islamic Republic of Iran', Alternatives 29: 115-138.

Hurd, Elizabeth Shakman, 2006. 'Negotiating Europe: The Politics of Religion and the Prospects of Turkish Accession', Review of International Studies 32: 401-418.

İnalcık, Halil, 2006. Turkey and Europe in History. Istanbul: Eren.

Karpat, Kemal H., 2000. 'Historical Continuity and Identity Change or How To Be a Modern Muslim, Ottoman, and Turk', in Kemal H. Karpat, ed., Ottoman Past and Today's Turkey. Leiden: Brill (1-28).

Keyder, Çağlar, 1987. State and Class in Turkey: A Study in Capitalist Development. London: Verso.

Keyder, Çağlar, 2004. 'The Turkish Bell Jar', New Left Review 28: 65-84.

Kili, Suna, 1980. 'Kemalism in Contemporary Turkey', International Political Science Review 1(3): 381-404.

Kili, Suna, 2003. The Atatürk Revolution: A Paradigm of Modernization. Istanbul: İş Bankası Yayınları.

Lewis, Bernard, 1961. The Emergence of Modern Turkey. London: Oxford University Press.

Ling, L. H. M., 2002. Postcolonial International Relations: Conquest and Desire Between Asia and the West. New York: Palgrave.

McSweeney, Bill, 1999. Security, Identity and Interests: A Sociology of International Relations. Cambridge: Cambridge University Press.

Mardin, Şerif, 1973. 'Center-Periphery Relations: A Key to Turkish Politics?', Daedalus 102(1): 169-190.

Mardin, Şerif, 1977. 'Religion in Modern Turkey', International Social Science Journal 29(2): 279-297.

Mardin, Șerif, 1981. 'Religion and Secularism in Turkey', in Ali Kazancigil \& Ergun Özbudun, eds, Atatürk: Founder of a Nation State. Hamden, CT: Archon (191-219).

Mardin, Şerif, 1982. 'Turkey: Islam and Westernization', in Carlo Caldarola, ed., Religions and Societies: Asia and the Middle East. Berlin: Mouton (171-198).

Mazower, Mark, 2006. 'An International Civilization? Empire, Internationalism and the Crisis of the Mid-Twentieth Century', International Affairs 82(3): 553-566.

Mert, Nuray, 1998. 'Cumhuriyet, Laiklik ve Din' [The Republic, Secularism and Religion], in 75 Yılda Düşünceler Tartışmalar [75 Years of Ideas and Debates]. Istanbul: İş Bankası Yayınları (207-214).

Ozankaya, Özer, 1981. Atatürk ve Laiklik: Atatürkçü Düşüncenin Temel Niteliği [Atatürk and Laicism: Fundamental Quality of Atatürkist Thinking]. Istanbul: İş Bankası Yayınları.

Parla, Taha \& Andrew Davison, 2004. Corporatist Ideology in Kemalist Turkey. Syracuse, NY: Syracuse University Press.

Radikal (Istanbul), 2007. 'Müktesebat bizi parçalar' [Conditionality Would Dismember Us], 13 April.

Rustow, Dankwart A., 1957. 'Politics and Islam in Turkey, 1920-1955', in Richard N. Frye, ed., Islam and the West: Proceedings of the Harvard Summer School Conference on the Middle East, July 25-27, 1955. The Hague: Mouton \& Co. (69-107).

Said, Edward W., 1978. Orientalism. New York: Pantheon.

Said, Edward W., 1993. Culture and Imperialism. New York: Knopf.

Suzuki, Shogo, 2005. 'Japan's Socialization into Janus-Faced European International Society', European Journal of International Relations 11(1): 137-164.

Tachau, Frank, 1984. Turkey, the Politics of Authority, Democracy, and Development. New York: Praeger. 
Tank, Pinar, 2005. 'Political Islam in Turkey: A State of Controlled Secularity', Turkish Studies 6(1): 3-19.

Tanör, Bülent, 1998. 'Laikleş(tir)me Kemalistler ve Din' [Secularization, the Kemalists and Religion], in 75 Yılda Düşünceler Tartışmalar [75 Years of Ideas and Debates]. Istanbul: İş Bankası Yayınları (183-196).

Taylor, Charles, 1998. 'Modes of Secularism', in Rajeev Bhargava, ed., Secularism and Its Critics. Delhi: Oxford University Press (31-53).

Toprak, Binnaz, 1981. Islam and Political Development in Turkey. Leiden: Brill.

Toprak, Binnaz, 1988. 'The State, Politics, and Religion in Turkey', in Metin Heper \& Ahmet Evin, eds, State, Democracy and the Military: Turkey in the 1980s. Berlin: Walter de Gruyter (119-136).

Toulmin, Stephen E., 1990. Cosmopolis: The Hidden Agenda of Modernity. New York: Free Press.

Wæver, Ole, 1995a. 'Securitization and Desecuritization', in Ronnie D. Lipschutz, ed., On Security. New York: Columbia University Press (46-86).

Wæver, Ole, 1995b. 'What Is Security? The Securityness of Security', in Birthe Hansen, ed., European Security 2000. Copenhagen: Copenhagen Political Studies Press (222-254).

Wæver, Ole, 1998. 'Insecurity, Security, and Asecurity in the West European Non-War Community', in Emanuel Adler \& Michael Barnett, eds, Security Communities. Cambridge: Cambridge University Press (69-118).

Weldes, Jutta, 1999. Constructing National Interests: The United States and the Cuban Missile Crisis. Minneapolis, MN: University of Minnesota Press.

Weldes, Jutta, \& Diane Saco, 1996. 'Making State Action Possible: The United States and the Discursive Construction of "The Cuban Problem", 1960-1994', Millennium: Journal of International Studies 25(2): 361-395.

Weldes, Jutta; Mark Laffey, Hugh Gusterson, \& Raymond Duvall, eds, 1999. Cultures of Insecurity: States, Communities, and the Production of Danger. Minneapolis, MN: University of Minnesota Press.

Williams, Michael C., 1998. 'Identity and the Politics of Security', European Journal of International Relations 4(2): 204-225.

Wyn Jones, Richard, 1999. Security, Strategy, and Critical Theory. Boulder, CO: Lynne Rienner.

Yavuz, M. Hakan, 2003. Islamic Political Identity in Turkey. Oxford: Oxford University Press.

Yavuz, Ünsal, 1990. Atatürk: Imparatorluktan Milli Devlete [Atatürk: From Empire to Nation-State]. Ankara: Türk Tarih Kurumu.

Zhang, Yongjin, 1991. 'China's Entry into International Society: Beyond the Standard of "Civilization"', Review of International Studies 17(1): 3-16. 